\title{
E-government effectiveness: a rocket model of contributing user-related factors
}

\author{
Mohammad I. Merhi* \\ Department of Decision Sciences, \\ Judd Leighton School of Business and Economics, \\ Indiana University South Bend, \\ 1700 Mishawaka Avenue, \\ South Bend, IN 46634, USA \\ Email: mmerhi@iusb.edu \\ *Corresponding author
}

\section{Kai S. Koong}

School of Economics and Management, Xidian University, 2 South Taibai Road, Chang'an, Xi'an, Shaanxi, China Email: karlkoong@hotmail.com

\begin{abstract}
This paper proposes an extended and holistic model of e-government effectiveness and user factors in the areas of technology acceptance model, contingency theory, and general systems theory used as the basis for the development of the 'Rocket Model' to demonstrate how e-government initiatives can be effective. The model is validated using two methods: (1) well established theories and (2) the five component model of an information system. A quantitative tool based on weighted scores is also used to assess the model and demonstrate its usefulness for best practices.
\end{abstract}

Keywords: e-government effectiveness; rocket model; security; transparency; trust; user factors; weighted score method.

Reference to this paper should be made as follows: Merhi, M.I. and Koong, K.S. (2016) 'E-government effectiveness: a rocket model of contributing userrelated factors', Int. J. Services and Standards, Vol. 11, No. 1, pp.1-19.

Biographical notes: Mohammad I. Merhi is an Assistant Professor at the Judd Leighton School of Business and Economics at the Indiana University South Bend. His research interests include behavioural aspects of information security and privacy, adoption and implementation of information systems in organisations, and e-government systems. He has published his research in several leading journals. He has also presented his research at leading international and national conference meetings and workshops including the International Conference on Information Systems (ICIS), Americas Conference on Information Systems (AMCIS), Decision Sciences Institute (DSI), and Southwest Decision Sciences Institute. He is also a reviewer for several journals.

Kai S. Koong is a Guest Professor of the School of Economics and Management at Xidian University, Xi'an, Shannxi, China, and an Honorary Professor of Caritas Institute of Higher Education in Hong Kong. He is an Editor-in Chief of the International Journal of Services and Standards and the 
International Journal of Electronic Healthcare. He is a well published writer and is a recipient of the Decision Sciences Institute-Southwest Region Educator of the Year Award. His areas of research specialisation are in e-commerce, global information systems, health information technology, and mobile learning.

\section{Introduction}

In the last two decades, the advancement of the technology, especially in the arena of Information and Communications Technologies (ICTs), was remarkable. The widespread availability of internet access and technologies has helped ICTs to grow very fast (Cilan, Bolat and Coşkun, 2009). These technologies are aimed to improve the efficiency and effectiveness of large bureaucratic organisations. Alongside these advancements, the government is looking for technologies to facilitate the monitoring and interoperation of their processes, lower the operating costs, provide faster service to citizens, and eliminate redundant IT development across agencies in order to improve the service delivery to citizens (Goings, Young and Hendry, 2003; Kumar et al., 2007). As a result, they emphasised the need for advanced ICTs when they formed their policies (Choudrie, Grey and Nicholas, 2010; Cilan, Bolat and Coşkun, 2009) and they started to invest an enormous amount of resources in e-government (Hackney, Desouza and Chau, 2008; Park, 2008; Rufin et al., 2014).

E-government is a cost-effective and convenient means (Kumar et al., 2007; Turban et al., 2015) that helps in promoting openness and transparency (Shirazi, Gholami and Añón Higón, 2009), reducing corruption (Bertot, Jaeger and Grimes, 2010), enhancing relationships between government employees and citizens (Evans and Yen, 2006), allowing citizens to track activities (DiCaterino and Pardo, 1996), and monitoring and controlling behaviours of government employees (Bertot, Jaeger and Grimes, 2010). Thus, e-government no longer appears to be a matter of choice for governments, but it is a necessity for any country wishing to enter the twenty-first century as a competitive nation (Yang, Harris and Whitfield, 2009). This paper presents a model called 'Rocket Model' which demonstrates how e-government initiatives can be effective.

In literature, e-government has been given a variety of definitions ranging from the general and simple such as, "the delivery of government information and services through the internet or other digital means" (Reddick and Frank, 2007; West, 2004), to definitions that include more ICTs in addition to the internet and the Web, such as "database, networking, discussion support, multimedia, automation, tracking and tracing, and personal identification technologies" (Jaeger, 2003). However, the World Bank's (2008) definition remains the most comprehensive definition. It defines e-government as: "the use by government agencies of information technologies (such as Wide Area Networks, the internet, and mobile computing) that have the ability to transform relations with citizens, businesses, and other arms of government. These technologies can serve a variety of different ends: better delivery of government services to citizens, improved interactions with business and industry, citizen empowerment through access to information, or more efficient government management. The resulting benefits can be less corruption, increased transparency, greater convenience, revenue growth, and/or cost reductions". This comprehensive definition implies that 
e-government includes three web-based interactions: Government-to-Government, Government-to-Citizens, and Government-to-Businesses.

As mentioned previously, e-government initiatives are increasingly capturing the attention of all governments around the world because e-government helps them achieve significant cost reductions, provide faster service to clients, and eliminate redundant IT development across agencies (Tolbert, Mossberger and McNeal, 2008; Turban et al., 2015). Moreover, e-government systems aid in the collection of information which helps decision makers serve citizens more effectively (Evans and Yen, 2006). Therefore, e-government emerges as a way to increase the citizens' trust in governments and to improve the relationship between citizens and public administration (Morgeson, VanAmburg. and Mithas, 2011).

While it is true that e-government has many advantages that help both governments and citizens achieve efficiency and satisfaction, it was not clear whether citizens will embrace the use of such services (Levy, Bagby and Trauth, 2013). Citizens are supposed to interact with the e-government and thus are the ones who will identify whether these systems are effective or not. Researchers have investigated e-government effectiveness (e.g., Dolan, 2014; Merhi and Koong, 2013). While it is true that each of these studies is significant in its way, they are limited in scope because until today there has been no comprehensive model of e-government effectiveness with user-related factors only. Based on previous literature in e-government, e-commerce, and systems design, this study presents an integrated yet dynamic framework, called the 'Rocket Model,' which covers users-related factors to e-government effectiveness andbrief discussions about these factors are discussed in the following paragraphs.

To begin with, e-government sites should be designed and operated in an accessible manner so even persons with limited knowledge in using computers can easily find the information they need and provide the information requested by the government agencies with which they are dealing (Schedler and Summermatter, 2007). In order to make the usage of e-government easy, navigations should be used to satisfy user expectations (Baker, 2009).

E-government is more than a website with governmental information, forms, and public services. Previous researchers (Fang, 2002; Janssen et al., 2011) argue that e-government is analogous to e-commerce. While e-commerce allows businesses to transact with each other more efficiently (B2B) and brings customers closer to businesses (B2C), e-government aims to make the interaction between government and citizens $(\mathrm{G} 2 \mathrm{C})$, government and business enterprises (G2B), and interagency relationships $(\mathrm{G} 2 \mathrm{G})$ more friendly, convenient, transparent, and inexpensive. Based on this, one can argue that to some extent e-government improvements will continue to depend on the technical advances the private sector brings to e-commerce since these two types of systems are alike.

Moreover, similar to e-commerce and other online transactions, researchers found that trust is a fundamental factor for e-government adoption and effectiveness (Dawes, 2008; Kim and Lee, 2012; Mahmood, Osmani and Sivarajah, 2014; Morgeson, VanAmburg and Mithas, 2011). Trust of the e-government refers to one's perceptions regarding the authenticity and ability of the agency providing the service (Carter and Weerakkody, 2008). With the uncertainty of using an open technological infrastructure, such as the internet; citizens need assurance that their online transactions, including personal information, are secure (Alharbi, Papadaki and Dowland, 2014; Kuzma, 2010). In order to support e-government initiatives, citizens must believe that the 
government agencies possess the technical skills and the technologies necessary to execute and secure e-government systems. Finally, while e-government has the potential to improve government transparency, responsiveness, and accountability, e-services will only be adopted if citizens deem them trustworthy (Belanger and Carter, 2008). Otherwise, the confidence in e-government systems will decrease and resistance will increase.

\section{Statement of the problem}

E-government's objective is to engage citizens in a user-centred fashion and to develop efficient as well as effective government services and delivery systems (Bertot, Jaeger and McClure, 2008). In general, e-government enables its stakeholders to reach two benefits. The first benefit includes governments being able to provide services and resources designed to meet the users' needs, including citizens, residents, government employees, and such others. The second benefit is that governments will gain economies of scale, reduce costs, and provide technology-enabled user services. The need and the anticipation to achieve these two goals have led governments to spend huge amounts of resources on these systems (Hackney, Desouza and Chau, 2008; Peristeras et al., 2009). As a matter of fact, the spending on these systems is still growing at a fast rate (Ngafeeson and Merhi, 2013).

According to a report released by UNDP in 2013, in 2012 the overall global e-governance expenditures increased by $14 \%$; the e-service delivery expenditure increased by $28 \%$; and the expenditures in e-participation increased by $117 \%$ (UNDP, 2013). In 2012, the expenditure in Latin America increased by 31\% compared to 2011 (UNDP, 2013). According to The global e-government outlook (2012), overall $80 \%$ of the governments spend less than $1 \%$ of their total federal operating budget on IT related projects, while $20 \%$ spend up to $5 \%$ of their budgets.

These huge amounts of resources are invested by governments in order to achieve success. Unfortunately, analyst reports still point out that the return on e-government investments is very low or negative in many cases because these projects often fail to improve service quality (Howard, 2013; Kinder, 2010). For instance, it was expected by IRS to have $80 \%$ of taxpayers filing electronically by 2007 (Koong, Bai and Liu, 2008), whereas this date was postponed later to 2012. On a survey, respondents indicated that they do more information gathering than transacting with e-government (Barr, 2007) which is far from the objective of e-government. It is also not clear whether citizens will adopt and keep on using these systems for a long period of time (Weerakkody et al., 2013a). This could be a result of two issues.

First, the effectiveness of e-government has a direct relationship with the willingness and the trust of the citizens to adopt the system of e-government or not. Achieving a high level of advancement in the technology does not necessarily mean that the government should have an effective e-system. For instance, some countries have used their technological and educational abilities to create e-government structures, while citizens of other countries having the same resources are not trusting e-government structures, and thus development has been slower (Evans and Yen, 2006). In fact, 19 out of 22 countries $(86 \%)$ ranked the telephone as the least easy to use and the most trustable out of four channel options (telephone, internet, in person and mail) (Accenture, 2005). 
A second issue that arises is the web advancements and the fast development of commercial sites which provide citizens with more innovative services than e-government sites do. Comparing public to private systems lead the users to not adopt the governments' systems as it has been found in many cases that the rate of adoption of e-government to be much less than expected (Ahmad, Markkula and Oivo, 2013) and the satisfaction with government websites to decline (Park, 2008).

\section{Statement of the objective}

Governments from all over the world are looking for ways to achieve success in e-government implementation especially after investing enormous amounts of resources in this project (Hackney, Desouza and Chau, 2008; Kassen, 2014; Peristeras et al., 2009). Based on previous literature in e-government, e-commerce, and design of websites, this study presents the 'e-Government Rocket Model' with four primary aims. The first aim is to identify and extract the users-related factors impacting the e-government effectiveness and then present them in an integrated model. The second aim is to present a dynamic model comprised of four major compartments: trust, functionality, technology, and selfefficacy, as well as enabled factors. In this study, trust is the most important compartment with a big influence toward e-government effectiveness. Besides trust, the other usersrelated factors are presented in order to develop a holistic model. To achieve the success of e-government, it is critical to understand the factors that influence citizens' acceptance of e-government services (Fu, Farn and Chao, 2006) because the success of e-government initiatives is to rely upon the citizens' willingness to use these services (Weerakkody et al., 2013b). The third objective is to validate the presented model using two methods:

1 Well established theories such as the technology acceptance model, contingency theory, as well as the general systems theory

2 The five component model of an information system. The final objective is to present an example to demonstrate how the model can be measured and applied in practice.

The presented model is a holistic, flexible, and dynamic framework expected to help both researchers and governments' decision makers. Governments' decision makers will find in this study a powerful means for identifying fundamental user-related factors which can lead to success. Moreover, based on the level of services the governments provide to the citizens, decision makers can identify which factors should be more emphasised than others in order to gain a higher level of satisfaction and, as a result, achieve a higher level of e-government effectiveness. Furthermore, the e-government rocket model is flexible such that it can be used in different countries: emerging or developed. Different countries have different perspectives and different resources; depending on its use, it can be used as an integrated tool with all the factors or a few of them. For researchers, the framework presented can be used as a foundation for assessing the contribution level of each factor, as well as the contribution level of each compartment.

\section{Proposed model and taxonomy}

The e-government rocket model is based on previous literatures in the e-government, e-commerce, and systems design. The model has important characteristics, highlighted below. 
Firstly, this is a dynamic model. The trust of the users is the most important part of the rocket. It is the engine that pushes the rocket forward toward the e-government effectiveness. Other factors and compartments are also critical and have influence on effectiveness. It should be noted here that in addition to the factors, enablers have a role toward achieving effectiveness. The combination of all these factors together leads to e-government effectiveness.

Secondly, it is an integrated model which includes factors extracted from different literature. Trust is a pertinent factor that can either enhance or diminish people's assurance in e-government technology. In e-commerce adoption literature, trust was found to be an important factor because electronic transactions involve sharing of private information such as credit card details, home address etc. Thus, in order to conduct e-commerce programs for consumers without inhibition, they need to trust the credibility of the system (Kolsaker, Lee-Kelley and Choy, 2004; McKnight, Choudhury and Kacmar, 2002). Similarly in e-government, users need to trust the government as well as the system before they share their information and transact with the system.

Finally, this is a flexible model. Depending on the level of services provided by the government to its citizens, along with the resources they have (developed vs. emerging countries), a government can affect certain policies or show progress in certain factors which would improve the effectiveness of e-government.

An illustration of the e-government rocket model is depicted in Figure 1.

Figure 1 The e-government rocket model

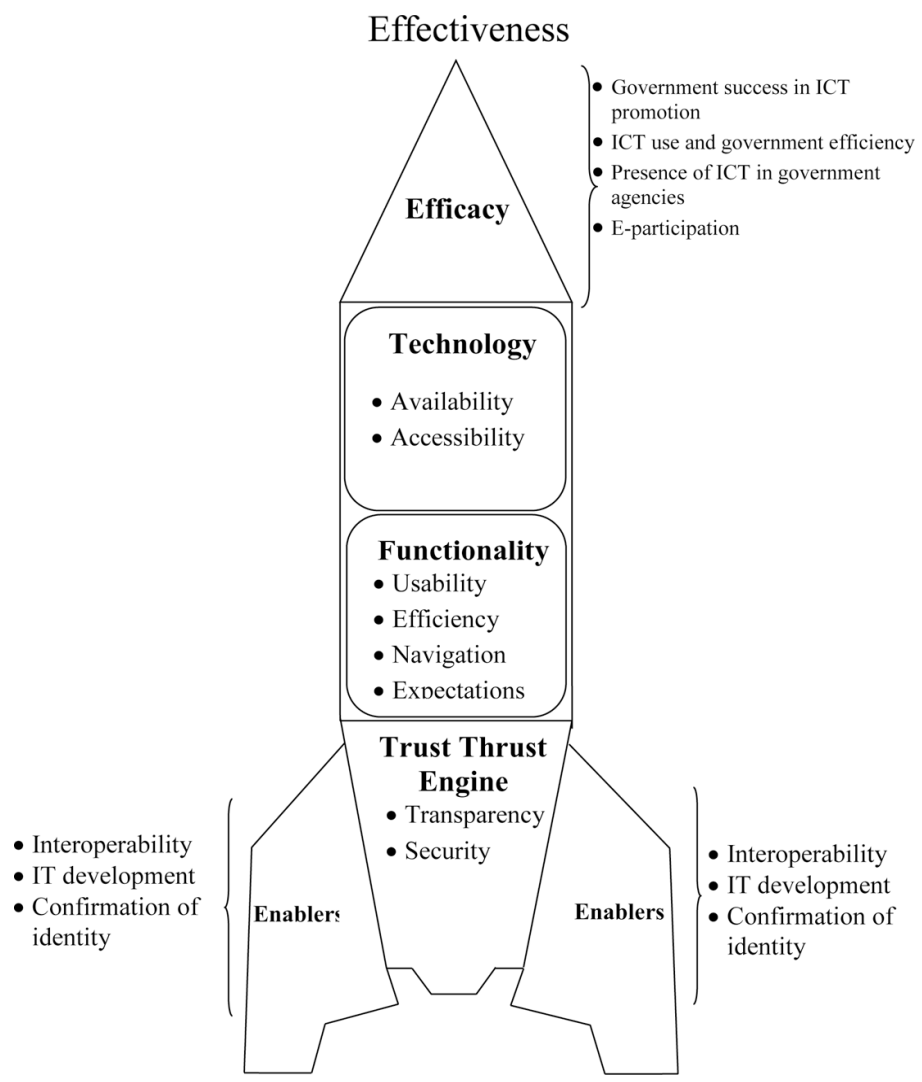




\subsection{Trust thrust engine}

Rotter (1967) defines trust as an expectancy that the promise of an individual or group can be relied upon. Trust is an essential element in all aspects in all cultures, including government. However, the processes by which trust is built, destroyed, used, or abused differ from one culture to another (Dawes, 2008). As mentioned before, all countries developed or emerging - are trying to succeed in applying e-government. E-government allows citizens to participate in the democratic institutions and change the governments' processes to be accessible, transparent, effective and participative (Tolbert and Mossberger, 2006). Therefore, e-government arises as a way of increasing the citizens' trust in governments and improving the valuations made concerning political management (García-Sánchez, Rodríguez-Domínguez and Frias-Aceituno, 2013).

However, citizens' confidence in the government agency's ability to provide online services is also necessary to the diffusion of e-government initiatives. Belanger and Carter (2008) state that trust in the agency has a major impact on the use of a technology. Thus, in order to succeed in e-government implementations and let the citizens adopt the system, users must first believe that the government's agencies are capable and possess the technical skills necessary to execute and secure e-government systems.

When it comes to personal information, people may doubt the accuracy of the system especially with the increasing number of identity theft cases. Therefore, transparent, accurate, reliable interaction with e-government service providers will increase the citizens' confidence and acceptance of e-government services. In e-government, trust is composed from the trust of the government as well as the reliability of the enabling technology (Carter and Belanger, 2005; Dombrowski et al., 2014; Mahmood, Osmani and Sivarajah, 2014).

\subsubsection{Transparency and accountability}

Accountability is the relationship between the system and citizens in which the system is held to account for its performance by the citizens (Kelly, 2003) while transparency is the literal value of accountability (Pina, Torres and Royo, 2010). Nowadays, transparency and the right to access government information are internationally regarded as essential to democratic participation (Bertot, Jaeger and Grimes, 2010). Trust in government, prevention of corruption, informed decision-making, and accuracy of government information are some of the advantages of the transparency. In e-government, transparency refers to the extent to which government makes information about internal decision processes and procedures available to the public. So, transparency is concerned for bringing the government's political agenda closer to citizens with the use of the internet (Pina, Torres and Royo, 2010). The higher the satisfaction with e-government transparency and accountability, the higher the level of trust in government will be (Welch, Hinnant and Moon, 2005).

\subsubsection{Security and privacy}

Security can be defined as the protection against incidents that cause harm to data or network in the form of destruction, non-protection, modification, mismanagement and abuse. Data regarding citizen-government transactions, and the content of those transactions from online searches to online transactions, need to be highly secured and 
protected by the government in order to prevent misuse and fraud (Alharbi, Papadaki and Dowland, 2014; Dawes, 2008; Fang, 2002). Citizens must feel confident that private information they submit will not be lost, sold, or otherwise misused (DeBenedictis et al., 2002; Kuzma, 2010). This means that the higher the level of security of the e-government, the higher is the level of citizens' confidence and trust to use these systems. For instance, if citizens are confident about the system, especially when dealing with personal information or financial transactions with the government, they use it; otherwise, they search for other means to satisfy their needs.

Privacy enables citizens to find out how their information may be used and what disclosures of their information have been made. It allows citizens to find out how their information is going to be protected and know that the people and systems handling their information have been properly trained and designed to protect their privacy. Generally, privacy limits release of information to the minimum number of avenues reasonably needed for the purpose of the disclosure. When dealing with electronic transactions, citizens feel that lack of privacy protection is the biggest barrier to conduct transactions online. For instance, according to a survey by the Council for Excellence in Government, $64 \%$ of respondents reported concern about government computers being vulnerable to hackers and $65 \%$ were very concerned about identity theft (Swanson, 2002).

\subsection{Functionality}

Functionality is the design of the technologies to include features desired by users (Bertot, Jaeger and Grimes, 2010). Simply, it is the characteristics that help users/citizens accomplish what they need to do on the system. It does not matter how aesthetically pleasing the website/system is as long as the users cannot find what they need. In general, how well the system works has a lot to do with how well it has been designed and developed. As a result, involving commonly accepted routines that online users expect on the website such as search function, frequently asked questions or other tools are essential if it has a large number of pages or extensive content. Otherwise, people may not stay on a website that does not provide easy access and do not come back to a website that does not function properly.

\subsubsection{Usability}

Usability is the design of technologies in such ways that are intuitive and allow users to engage in the content embedded within the technology (Bertot, Jaeger and Grimes, 2010). Simply, this refers to the degree of ease of use of e-government systems (Davis, 1989). In general, ability is a concept that cannot be measured, but is related to several usability parameters that can be measured. Measurable usability parameters fall into two broad categories: subjective user preference measures, which assess how many the users like the system, and objective performance measures, which measure how capable the users are at using the system (Nielsen and Levy, 1994). Usually, the higher the perceived ease and perceived usefulness, the higher the adoption of the e-government by the citizens is (Davis, 1989) and the higher the effectiveness of the systems will be.

\subsubsection{Efficiency}

Efficiency is the capability of the system to provide appropriate performance, relative to the amount of resources used, under stated conditions. Thus, it is the degree to which an 
outlet effectively uses its resources (Rawashdeh and Matalkah, 2006; Rojas and Perez, 1995). A way to create customer value is the development of a website or e-government system that is easy to use. That is, visitors have no problem in finding what they are looking for (Schedler and Summermatter, 2007). The conventional wisdom holds that if someone cannot do what they want to do at a website or a system, it has no usefulness for the user (Baker, 2009). As a consequence, a user will not stay long and will not come back to use the system. Thus, e-government sites should be designed and operated so that even those citizens who do not know much about computer usage can easily find the information they need. It should also provide the information requested by the government agencies with which they are dealing (Fang, 2002).

\subsubsection{Navigation}

Navigation is "the process whereby people determine where they are, where everything else is, and how to get to particular objects or places" (Baker, 2009). Simply, navigation allows for users to move around the website and manoeuvre to specific destinations. A good navigation system should promote the right pages to the users. Therefore, it is very important to structure the site in such a manner that citizens are able to locate information quickly. A good system is the one that can foretell the action of the users and helps users receive the full benefit of visiting the website. It is extremely difficult in governments' websites to guess where relevant content might be located without the help of a navigation system. Keeping in mind, people who are surfing the governments' web get very impatient when they cannot find what they want quickly and especially if they do not have a high level of experience with computers and internet usage. Fortunately, good interface and information design may provide such support and offer new ways of navigating (Jul and Furnas, 1997) which leads citizens to adopt the e-government faster.

\subsubsection{Meeting user expectations}

Usually citizens tend to develop expectations of what information will be available and where it should be located in the systems. In fact, these expectations do not exist in many e-government systems since these governments do not give high importance for these factors. In order to satisfy citizens in meeting their expectations, governments have to build systems that are systematic and up-to-date in quickly helping users find what they are looking for. Moreover, the design and the organisation of the information should be taken into consideration.

\subsection{Technology}

Technology refers to the process of offering government services through e-government systems. Government services offered through the systems are a key motivation for the citizens to adopt and use e-government. The need for these services is very important; however, it is sometimes limited. Thus, the adoption of the e-government is directly affected by the availability and the accessibility of the services.

\subsubsection{Availability}

Availability is the degree of information and services offered by the systems to the citizens. In many cases, governments offer random information that may or may not be of 
benefit for the citizens. This directly affects the adoption as well as the effectiveness of the e-government systems. E-government systems should be designed in such a way so as to help citizens achieve what they want in an easy way without any complications. The governments should determine the level of the services provided to the citizens. Pushing information of no importance to the citizens drives them to distrust, to not use the systems, and to look for other simple means to satisfy their needs. Similarly, not offering the needed information will have the same result. An effective system, then, is the one with the specific and accurate information the citizens require.

\subsubsection{Accessibility}

Accessibility refers to the ease of obtaining information from e-government systems. This information should be provided to all citizens equally. Thus, it should be taken into account the special needs of the disabled, and make it possible for them to use these systems as easily as the non-disabled (Bertot, Jaeger and Grimes, 2010; Henriksson et al., 2007). If a government system does not provide access to citizens who are physically disabled, or who speak a different language than the official language of the country, it fails to serve its full constituency. In fact, not all potential users and information seekers equally benefit from the systems. The difference between the levels of accessibility does not only exist between developed and emerging countries, but also between the users to the same country (those who have the knowledge and those who do not have the knowledge of where to find the information). It should be noted that only $55 \%$ of adult Americans now have broadband internet connections at home (Horrigan, 2008) which highlights a big problem. Internet access can be a major barrier for most citizens and especially in emerging countries since this low percentage was found in USA. Now more and more people have internet access, to government websites and demand an efficient and responsible digital government (Kim, 2007).

\subsection{Efficacy}

The efficacy of the governments in providing the users what they need from these systems can be measured by different factors such as:

- the successfulness of the government in promoting the use of ICTs in a country

- testing whether the usage of ICTs by the government improved the efficiency of government services in the country

- the extent of usage of ICTs by the government agencies in the country

- the assessment of the usefulness of government websites in providing online information, participatory tools, and services to citizens.

\subsection{Enablers}

Enablers are factors that help achieve e-government effectiveness in addition to the previously mentioned factors. First, there is the interoperability between government agencies. To succeed in e-government transformation, a fundamental cultural shift will need to take place at every level of the government. The public sector should not be perceived as a collection of disparate agencies delivering services to citizens. Rather, the public sector should be viewed as a coordinated entity that delivers services to the 
community in ways that best suit citizens' needs. By doing so, it becomes easier for citizens to access any necessary data/information about anything they want while using one of the systems.

Another factor that can enable e-government effectiveness is a confirmation of identity. This could be a question that replaces the signature or the stamp in the paper applications. As mentioned previously, citizens are aware of identity theft; thus, they need a secure and convenient way to identify themselves.

Finally, the level of information technology development could be another important predictor of the e-government effectiveness. To deliver effective and responsive public services online, government agencies are expected to regularly update their websites by using advanced software and information technology or by establishing advanced information infrastructure. In fact, information technology is developing so fast and often, governments' information technology is outdated.

\section{Proposed validation}

In this study, two concepts are used to validate the model. First, the factors of the e-government rocket model are each validated across three major theories. These theories are namely: technology acceptance model (TAM), general systems theory (GST), and contingency theory (CT). Table 1 includes these theories, their definitions and the reason why they are used in this study. Second, the factors of the e-government rocket model are associated to the five components of Information Systems model.

Table 1 Theories used, their definitions and their importance

\begin{tabular}{|c|c|c|}
\hline Theory & Definition & Reference \\
\hline The & The TAM, first proposed by Davis (1989), from the theory of & Davis \\
\hline technology & Reasoned Action (1975); has become a generally accepted & (1989); \\
\hline acceptance & model for examining technology acceptance. Davis (1989) & Fishbein \\
\hline model (TAM) & hypothesised that technology acceptance was a function of & and Ajzen \\
\hline & $\begin{array}{l}\text { perceived usefulness and perceived ease of use. It has also been } \\
\text { expanded and antecedents were added to the original model. In } \\
\text { e-government literature, the TAM is also used as a framework } \\
\text { to measure e-government acceptance and effectiveness. }\end{array}$ & $(1975)$ \\
\hline \multirow{9}{*}{$\begin{array}{l}\text { The general } \\
\text { systems } \\
\text { theory (GST) }\end{array}$} & \multirow{9}{*}{$\begin{array}{l}\text { The general systems theory was proposed in the } 1940 \text { 's by the } \\
\text { biologist Ludwig von Bertalanffy. He states that a system is an } \\
\text { integration of some components held together through some } \\
\text { common and cohesive bond. von Bertalanffy noted these } \\
\text { components are open to, and interact with, their environments. } \\
\text { In addition, they can acquire qualitatively new properties } \\
\text { through emergence; thus, they are in a continual evolution. } \\
\text { Regardless of the type of the system, all systems should have } \\
\text { these mentioned properties. E-government systems fall into this } \\
\text { category since it is composed of different parties and connect } \\
\text { citizens to governments. }\end{array}$} & \multirow{9}{*}{$\begin{array}{l}\text { Von } \\
\text { Bertalanffy } \\
(1976)\end{array}$} \\
\hline & & \\
\hline & & \\
\hline & & \\
\hline & & \\
\hline & & \\
\hline & & \\
\hline & & \\
\hline & & \\
\hline \multirow{7}{*}{$\begin{array}{l}\text { The } \\
\text { contingency } \\
\text { theory (CT) }\end{array}$} & The contingency theory is a theory that has been widely used in & \multirow{7}{*}{$\begin{array}{l}\text { Drazin and } \\
\text { Van de Ven } \\
(1985)\end{array}$} \\
\hline & management and leadership literature. Contingency theory starts & \\
\hline & with the theme of 'it depends,' arguing that the solution to any & \\
\hline & one managerial problem is contingent on the factors that are & \\
\hline & impinging on the situation. In the case of e-government, it is & \\
\hline & argued that its effectiveness is contingent on certain factors & \\
\hline & & \\
\hline
\end{tabular}


As mentioned, the factors of the e-government rocket model are each validated across three major theories. Table 2 illustrates how these variables are interrelated to these theories. The ' $\mathrm{X}$ ' symbol indicates that the particular factor has been linked to the theory. As indicated in Table 2, one can see that each of the factors can be explained by one or more approaches.

Table 2 Linking the factors of the model to three theories

\begin{tabular}{|c|c|c|c|}
\hline Factors & $\begin{array}{c}\text { Technology } \\
\text { acceptance model }\end{array}$ & $\begin{array}{c}\text { General systems } \\
\text { theory }\end{array}$ & Contingency theory \\
\hline Trust & $\mathrm{X}$ & & \\
\hline Transparency & $\mathrm{X}$ & $\mathrm{X}$ & $\mathrm{X}$ \\
\hline Security & $\mathrm{X}$ & $\mathrm{X}$ & $\mathrm{X}$ \\
\hline \multicolumn{4}{|l|}{ Functionality } \\
\hline Usability & $\mathrm{X}$ & $\mathrm{X}$ & $\mathrm{X}$ \\
\hline Efficiency & $\mathrm{X}$ & $\mathrm{X}$ & $\mathrm{X}$ \\
\hline Navigation & $X$ & $\mathrm{X}$ & \\
\hline Usability & $\mathrm{X}$ & $X$ & $\mathrm{X}$ \\
\hline Efficiency & $\mathrm{X}$ & $X$ & $\mathrm{X}$ \\
\hline Expectations & $X$ & $\mathrm{X}$ & $\mathrm{X}$ \\
\hline \multicolumn{4}{|l|}{ Technology } \\
\hline Availability & $\mathrm{X}$ & $\mathrm{X}$ & $X$ \\
\hline Accessibility & $\mathrm{X}$ & $\mathrm{X}$ & $X$ \\
\hline \multicolumn{4}{|l|}{ Efficacy } \\
\hline Gov't success in ICT & $\mathrm{X}$ & $\mathrm{X}$ & $\mathrm{X}$ \\
\hline ICT and gov't efficiency & $\mathrm{X}$ & $\mathrm{X}$ & $\mathrm{X}$ \\
\hline Presence of ICT in gov't & $X$ & $\mathrm{X}$ & $X$ \\
\hline E-participation & $\mathrm{X}$ & $\mathrm{X}$ & $\mathrm{X}$ \\
\hline \multicolumn{4}{|l|}{ Enablers } \\
\hline Interoperability & $\mathrm{X}$ & $\mathrm{X}$ & $\mathrm{X}$ \\
\hline Confirmation of identity & $X$ & $\mathrm{X}$ & $\mathrm{X}$ \\
\hline IT development & $\mathrm{X}$ & $\mathrm{X}$ & $\mathrm{X}$ \\
\hline
\end{tabular}

For example, it can be seen that all the factors of the model can be linked to the general systems theory. This is because e-government systems are broad systems composed of different parts, all essential to the success and the effectiveness of these systems. Also based on literature, the contingency theory was found to be related to each set of the determinants. As a matter of fact, e-government are systems that have been implemented in different countries around the world (emerging and developed). Different countries have different resources, perspectives, and priorities for separate factors. Finally, one can see that the technology acceptance model variables such as ease of use and usefulness are clearly linked with such factors as service delivery. Since the variables of the e-government rocket model are associated with these well-established theories, it can be concluded that the proposed framework does have high theoretical construct validity.

Another concept that can be used to validate the present model is the association of the model's factors to the five components of information systems (O'Brien and Marakas, 2007). The five components of an information systems are hardware, software, network, data, and people. Usually people have to rely on hardware that uses software to send information or data through a network. Similarly, this can be applied to e-government where citizens use computer or any other hardware device to access the systems to get or store data from or to the governments' database. 
Similar to the previous method, Table 3 illustrates how the factors of the e-government rocket model are interrelated to the components of an information systems. The ' $X$ ' symbol means that the particular component has been linked to a factor of the presented model. As can be seen in Table 3, most of the factors are related to the components. For instance, 14 of the factors are associated with the component 'hardware,' whereas all of the factors are connected to the components 'software' and 'data.' As a result, since all the factors are linked to the information systems components, it can be concluded that the proposed framework does have high theoretical construct validity.

Table 3 Linking the components of the e-government rocket model to the five components of an information systems

\begin{tabular}{lccccc}
\hline & Hardware & Software & Network & Data & People \\
\hline $\begin{array}{l}\text { Trust } \\
\text { Transparency }\end{array}$ & & $\mathrm{X}$ & $\mathrm{X}$ & $\mathrm{X}$ & $\mathrm{X}$ \\
Security & $\mathrm{X}$ & $\mathrm{X}$ & $\mathrm{X}$ & $\mathrm{X}$ & $\mathrm{X}$ \\
Functionality & & & & & \\
Usability & $\mathrm{X}$ & $\mathrm{X}$ & & $\mathrm{X}$ & $\mathrm{X}$ \\
Efficiency & $\mathrm{X}$ & $\mathrm{X}$ & $\mathrm{X}$ & $\mathrm{X}$ & $\mathrm{X}$ \\
Navigation & & $\mathrm{X}$ & $\mathrm{X}$ & $\mathrm{X}$ & $\mathrm{X}$ \\
Expectations & $\mathrm{X}$ & $\mathrm{X}$ & $\mathrm{X}$ & $\mathrm{X}$ & $\mathrm{X}$ \\
Technology & & & & & \\
Availability & $\mathrm{X}$ & $\mathrm{X}$ & $\mathrm{X}$ & $\mathrm{X}$ & $\mathrm{X}$ \\
Accessibility & $\mathrm{X}$ & $\mathrm{X}$ & $\mathrm{X}$ & $\mathrm{X}$ & $\mathrm{X}$ \\
Efficacy & & & & & $\mathrm{X}$ \\
Gov't success in ICT & $\mathrm{X}$ & $\mathrm{X}$ & $\mathrm{X}$ & $\mathrm{X}$ & $\mathrm{X}$ \\
ICT and gov't efficiency & $\mathrm{X}$ & $\mathrm{X}$ & $\mathrm{X}$ & $\mathrm{X}$ & $\mathrm{X}$ \\
Presence of ICT in gov't & $\mathrm{X}$ & $\mathrm{X}$ & $\mathrm{X}$ & $\mathrm{X}$ & $\mathrm{X}$ \\
E-participation & $\mathrm{X}$ & $\mathrm{X}$ & $\mathrm{X}$ & $\mathrm{X}$ & $\mathrm{X}$ \\
Enablers & & & & & \\
Interoperability & $\mathrm{X}$ & $\mathrm{X}$ & $\mathrm{X}$ & $\mathrm{X}$ & $\mathrm{X}$ \\
Confirmation of identity & $\mathrm{X}$ & $\mathrm{X}$ & $\mathrm{X}$ & $\mathrm{X}$ & $\mathrm{X}$ \\
IT development & & $\mathrm{X}$ & $\mathrm{X}$ & $\mathrm{X}$ & $\mathrm{X}$ \\
\hline
\end{tabular}

\section{Proposed assessment}

In this study, a simple yet comprehensive technique is used to quantitatively demonstrate how the proposed e-government rocket model can be assessed. This method is 'the weighted scoring method' which is a tool that provides a systematic process for selecting a system based on many criteria. This method is being used in project management in order to assess and choose the best project that suits the organisation (Schwalbe, 2007) as well as in the previous research (Wei, Liu and Koong, 2006). It is believed that this technique could be used to evaluate the e-government systems as well. The weighted method scoring is composed of three steps. 
The first step is to comparatively rate the importance of the factors of the e-government rocket model. Each factor is compared with all others factors in the model. For instance, the importance of the factors can be rated using a four-point scale where 4 is 'highly important', 3 is 'moderate', 2 is 'low', and 1 is 'no preferences'. Then the rating is inserted in the box that is relative to the two comparable factors. Figure 2 presents all the factors and their relative rates. For instance, checking the intersection between $\mathrm{A}$ and $\mathrm{E}$ is rated ' $2 \mathrm{~A}$ ', which means that a moderate importance preference of $\mathrm{A}$ compared to $\mathrm{E}$ is given. By adding the rate of each factor together, the bottom row of Figure 2 can be obtained.

Figure 2 Evaluation matrix for relative weighting of e-government rocket model factors

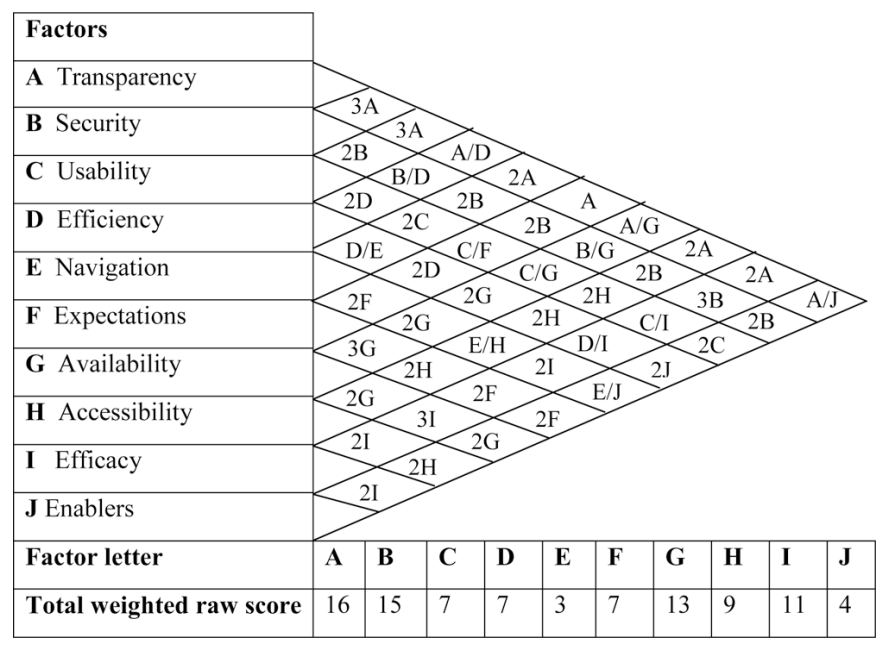

Note: 4-high importance, 3-moderate, 2-low, 1(no number)-no preferences

In the second step, the goal is to rate different e-government systems against the factors of the Rocket Model. The rates can be obtained using surveys or experts. Survey data can collected from users in government agencies and citizens. Experts are IT professional who have experience with systems design. Table 4 is an example that shows the system ratings of three e-government systems using a ten-point scale where 1 is very low and 10 is the highest grade given. In this case 'E-tax' received the highest rating but before determining the best option/system, one final stage is still needed.

Table 4 Rating potential e-government systems

\begin{tabular}{lccc}
\hline & & System & \\
\cline { 2 - 4 } Factors & Online auction & E-tax & Registration \\
\hline Transparency & 6 & 10 & 4 \\
Security & 4 & 9 & 5 \\
Usability & 3 & 7 & 8 \\
Efficiency & 5 & 6 & 3 \\
Navigation & 6 & 5 & 5 \\
Expectations & 4 & 8 & 7 \\
Availability & 7 & 7 & 5 \\
Accessibility & 3 & 8 & 4 \\
Efficacy & 5 & 9 & 6 \\
Enablers & 6 & 5 & 4 \\
\hline
\end{tabular}


In the third and final step, the total weights of the first and second matrices are used to build the third matrix which is presented in Table 5. By multiplying the weighted row score from Figure 2 by the rates of each factor of each system, a weighted score can be obtained for that particular factor of the particular system. Last, adding the weighted score for each system yields the total weighted score, based on which a ranking for the systems will be obtained. In this case, 'E-tax' is the best system with 739 points.

Table 5 Weighted score

\begin{tabular}{lccc}
\hline & \multicolumn{3}{c}{ System } \\
\cline { 2 - 4 } Factors & Online auction & E-tax & Registration \\
\hline Transparency (16) & 96 & 160 & 75 \\
Security (15) & 60 & 135 & 56 \\
Usability (7) & 21 & 49 & 21 \\
Efficiency (7) & 35 & 42 & 15 \\
Navigation (3) & 18 & 15 & 49 \\
Expectations (7) & 28 & 56 & 65 \\
Availability (13) & 91 & 91 & 36 \\
Accessibility (9) & 27 & 72 & 66 \\
Efficacy (11) & 55 & 99 & 16 \\
Enablers (4) & 24 & 20 & 463 \\
Total weighted score & 455 & 739 & 2 \\
Ranking & 3 & 1 & \\
\hline
\end{tabular}

\section{Conclusions, implications, and directions for future studies}

In today's environment, especially with the advancements of the ICTs, governments from all over the world are looking for ways to improve service delivery to citizens and achieve e-government effectiveness. This study provides a practical taxonomy model consisting of four major compartments. Specifically, the model presented is a systematic framework incorporating user-related factors which influence e-government effectiveness. Practically speaking, the best e-government practices depend on variables associated with technology acceptance model, general systems theory, and contingency theory. Simply put, these common theories means to be considered effective, all systems have to be accepted by users, hold a systematic nature, and need to be flexible.

It should be emphasised here that the model was validated using two methods: first, with sound and established theories, and second, with an association between the factors of the presented model and the five components of information systems. The theories include technology acceptance model, general systems theory, and contingency theory. Each of the classical theories used is commonly accepted as the basis for technology adoption as well as the technology effectiveness. In the same vein, the five components of information systems are well-known in the domain that can be applied to any system.

Furthermore, an assessment methodology was used in this study, which is simple and yet comprehensive, in order to demonstrate how the framework can be measured. By using experts' and users opinions, decision makers can find this method valuable. It should be noted that this method is a commonly used IS assessment tool in analysis and design, project management, and operation management. Thus, this model is practical and easy to assess. 
Like all models presented and assessed, users must take into consideration the resources and conditions available, since they may change over time or may vary based on other demographic factors. For example, countries have different levels of advancements, sizes, and cultures, as well as resource capabilities. The good news is this is a generic model that is dynamic and adaptive so it can be tailored to new factors to better fit the users. Obviously, additional research and modifications, as well as updating of the model by adding sub-compartments specific to users' needs will definitely enrich the body of knowledge about e-government effectiveness and usefulness of this framework and its content to best practice.

\section{References}

Accenture (2005) Leadership in Customer Service: New Expectations, New Experiences, Available online at http://www.accenture.com/SiteCollectionDocuments/PDF/leadership_ customerservice.pdf, (accessed on April 13, 2014).

Ahmad, M.O., Markkula, J. and Oivo, M. (2013) 'Factors afecting E-government adoption in Pakistan: a citizen's perspective', Transforming Government: People, Process and Policy, Vol. 7, No. 2, pp.225-239.

Alharbi, N., Papadaki, M. and Dowland, P. (2014) 'Security challenges of E-government adoption based on end users' perspective', IEEE 9th International Conference for Internet Technology and Secured Transactions (ICITST), London, pp.78-82.

Baker, D.L. (2009) 'Advancing e-government performance in the United States through enhanced usability benchmarks', Government Information Quarterly, Vol. 26, pp.82-88.

Barr, S. (2007) 'Public less satisfied with government websites', The Washington Post, Available online at http://www.washingtonpost.com/wpdyn/content/article/2007/03/20/AR200703200 1338.html, (accessed on April 13, 2014).

Belanger, F. and Carter, L. (2008) 'Trust and risk in e-government adoption', Journal of Strategic Information Systems, Vol. 17, pp.165-176.

Bertot, J.C., Jaeger, P.T. and Grimes, J.M. (2010) 'Using ICTs to create a culture of transparency: e-government and social media as openness and anti-corruption tools for societies', Government Information Quarterly, Vol. 27, pp.264-271.

Bertot, J.C., Jaeger, P.T. and McClure, C.R. (2008) 'Citizen-centered e-government services: benefits, costs, and research needs', The Proceedings of the 9th Annual International Digital Government Research Conference, Montreal, Canada, pp.137-142.

Carter, L. and Belanger, F. (2005) 'The utilization of e-government services: citizen trust, innovation and acceptance factors', Information Systems Journal, Vol. 15, No. 1, pp.5-25.

Carter, L. and Weerakkody, V. (2008) 'E-government adoption: a cultural comparison', Information Systems Frontier, Vol. 10, pp.473-482.

Choudrie, J., Grey, S. and Nicholas, T. (2010) 'Evaluating the digital divide: the silver surfer's perspective', Electronic Government, An International Journal, Vol. 7, No. 2, pp.148-167.

Cilan, C.A., Bolat, B.A. and Coşkun, E. (2009) 'Analyzing digital divide within and between member and candidate countries of European Union', Government Information Quarterly, Vol. 26, pp.98-105.

Davis, F.D. (1989) 'Perceived usefulness, perceived ease of use, and user acceptance of information technology', MIS Quarterly, Vol. 13, No. 3, pp.319-342.

Dawes, S.S. (2008) 'An exploratory framework for future e-government research investments', Proceedings of the 4lst Hawaii International Conference on System Sciences, Big Island, Hawaii, January 7-10, pp.1-8.

DeBenedictis, A., Howell, W., Figueroa, R. and Boggs, R.A. (2002) 'E-government defined: an overview of the next big information technology challenge', Issues in Information Systems, Vol. 3, pp.130-136. 
DiCaterino, A. and Pardo, T.A. (1996) 'The world wide web as a universal interface to government services,' Available online at: http://www.ctg.albany.edu/publications/reports/world_wide_ web/world_wide_web.pdf, (accessed on January 10, 2015).

Dolan, T.E. (2014) 'A six-dimensional strategic development tool for e-government effectiveness', Government e-Strategic Planning and Management, pp.105-124.

Dombrowski, L., Hayes, G.R., Mazmanian, M. and Voida, A. (2014) 'E-government intermediaries and the challenges of access and trust', ACM Transactions on Computer-Human Interaction, Vol. 21, No. 2. pp.1-22.

Drazin, R. and Van de Ven, A.H. (1985) 'Alternative forms of fit in contingency theory,' Administrative Science Quarterly, Vol. 30, No. 4, pp.514-539.

Evans, D. and Yen, D.C. (2006) 'E-government: evolving relationship of citizens and government, domestic, and international development', Government Information Quarterly, Vol. 23, pp.207-235.

Fang, Z. (2002). 'E-government in digital era: concept, practice, and development', International Journal of the Computer, the Internet and Management, Vol. 10, No. 2, pp.1-22.

Fishbein, M. and Ajzen, I. (1975) Belief, Attitude, Intention, and d: an Introduction to Theory and Research, Addison-Wesley, Reading, MA.

Fu, J., Farn, C. and Chao, W. (2006) 'Acceptance of electronic tax filing: a study of taxpayer intentions', Information \& Management, Vol. 43, No. 1, pp.109-126.

García-Sánchez, I.M., Rodríguez-Domínguez, L. and Frias-Aceituno, J.V. (2013) 'Evolutions in e-governance: evidence from Spanish local governments', Environmental Policy and Governance, Vol. 23, No. 5, pp.323-340.

Goings, D.A., Young, D. and Hendry, S.H. (2003) 'Critical factors in the delivery of e- government services: perceptions of technology executives', Communications of the International Information Management Association, Vol. 3, No. 3, pp.1-14.

Hackney, R., Desouza, K.C. and Chau, P. (2008) 'Egovernment strategies: ICT innovation in international public sector contexts', Journal of Strategic Information Systems, Vol. 17, pp.73-74.

Henriksson, A., Yi, Y., Frost, B. and Middleton, M. (2007) 'Evaluation instrument for e-government websites', Electronic Government, An International Journal, Vol. 4, No. 2, pp.204-226.

Horrigan, J.B. (2008) 'Adoption stalls for low-income Americans even as many broadband users opt for premium services that give them more speed', Pew Internet and American life project, Available online at http://www.pewinternet.org/ /media//Files/Reports/2008/PIP_Broadband_ 2008.pdf, (accessed on April 16, 2015).

Howard, A. (2013) 'What is the Return on Investment (ROI) of Open Government?', Available at: http:/e-pluribusunum.org/2013/07/19/what-is-the-return-on-investment-roi-of-open-govern$\mathrm{ment} /$ (accessed on May 01, 2015).

Jaeger, P.T. (2003) 'The endless wire: E-government as global phenomenon', Government Information Quarterly, Vol. 20, pp.323-331.

Janssen, M., Charalabibis, Y., Kuk, G. and Cresswell, T. (2011) 'Guest editors' introduction: e-government interoperability, infrastructure and architecture: state-of-the-art and challenges', Journal of Theoretical and Applied Electronic Commerce Research, Vol. 6, No. 1, pp.I-VIII.

Jul, S. and Furnas, G.W. (1997) 'Navigation in electronic worlds', Workshop Report ACM SIGCHI Bulletin, Vol. 29, No. 4, pp.44-49.

Kassen, M. (2014) 'Globalization of e-government: open government as a global agenda; benefits, limitations and ways forward', Information Development, Vol. 30, No. 1, pp.51-58.

Kelly, J. (2003) 'The audit commission: guiding, steering and regulating local government', Public Administration, Vol. 81, No. 3, pp.459-476.

Kim, C.K. (2007) 'A cross-national analysis of global e-government', Public Organization Review, Vol. 7, pp.317-329. 
Kim, S. and Lee, J. (2012) 'E-participation, transparency, and trust in local government', Public Administration Review, Vol. 72, No. 6, pp.819-828.

Kinder, T. (2010) 'E-government service innovation in the Scottish criminal justice information system', Financial Accountability \& Management, Vol. 26, No. 1, pp.21-41.

Kolsaker, A., Lee-Kelley, L. and Choy, P.C. (2004) 'The reluctant Hong Kong consumer: purchasing travel online', International Journal of Consumer Studies, Vol. 28, pp.295-304.

Koong, K.S., Bai, S. and Liu, L. (2008) 'Advancements in e-filing practices', International Journal of Electronic Finance, Vol. 2, No. 2, pp.211-226.

Kumar, V., Mukerji, B., Butt, I. and Persaud, A. (2007) 'Factors for successful e-government adoption: a conceptual framework', The Electronic Journal of e-Government, Vol. 5, No. 1, pp.63-76.

Kuzma, J. (2010) 'An examination of privacy policies of US Government Senate websites', Electronic Government, An International Journal, Vol. 7, No. 3, pp.270-280.

Levy, A., Bagby, J.W. and Trauth, E.M. (2013) 'E-government evolution in small municipalities in Pennsylvania in web 2.0 social environment: a poster', Proceedings of the 14th Annual International Conference on Digital Government Research, Quebec City, QC, Canada, pp.273-274.

Mahmood, M., Osmani, M. and Sivarajah, U. (2014) 'The role of trust in e-government adoption: a systematic literature review', Twentieth Americas Conference on Information Systems, Savannah, Georgia. pp.1-16.

McKnight, D.H., Choudhury, V. and Kacmar, C. (2002) 'Developing and validating trust measures for e-commerce: an integrative typology', Information Systems Research, Vol. 13, No. 3, pp.334-359.

Merhi, M.I. and Koong, K.S. (2013) 'E-government effectiveness: assessment of contributing governments' ICT usage factors', International Journal of Business and Systems Research, Vol. 7, No. 1, pp.1-24.

Morgeson, F.V., VanAmburg, D. and Mithas, S. (2011) 'Misplaced trust? Exploring the structure of the e-government-citizen trust relationship', Journal of Public Administration Research and Theory, Vol. 21, No. 2, pp.257-283.

Ngafeeson, M.N. and Merhi, M.I. (2013) 'E-government diffusion: evidence from the last decade', International Journal of Electronic Government Research, Vol. 9, No. 2, pp.1-18.

Nielsen, J. and Levy, J. (1994) 'Measuring usability: preference vs. performance', Communications of the ACM, Vol. 37, No. 4, pp.66-75.

O'Brien, J. and Marakas, G. (2007) Introduction to Information Systems, 4th ed., McGrawHill/Irwin, New York, NY.

Park, R. (2008) 'Measuring factors that influence the success of e-government initiatives', Proceedings of the 4lst Hawaii International Conference on System Sciences - 2008, Waikoloa, Big Island, HI, USA, pp.1-10.

Peristeras, V., Mentzas, G., Tarabanis, K.A. and Abecker, A. (2009) 'Transforming e-government and e-participation through IT', IEEE Intelligent Systems, Vol. 24, No. 5, pp.14-19.

Pina, V., Torres, L. and Royo, S. (2010) 'Is e-government leading to more accountable and transparent local governments? An overview', Financial Accountability \& Management, Vol. 26, No. 1, pp.3-20.

Rawashdeh, A. and Matalkah, B. (2006) 'A new software quality model for evaluating COTS components', Journal of Computer Science, Vol. 2, No. 4, pp.373-381.

Reddick, C.G. and Frank, H.A. (2007) 'The perceived impacts of e-government on U.S. cities: a survey of Florida and Texas city managers', Government Information Quarterly, Vol. 24, pp.576-594.

Rojas, T. and Perez, M. (1995) 'A comparison of three information system development methodologies related to effectiveness/efficiency criteria', International Symposium on Applied Corporate Computing (ISACC'95), Monterrey, Mexico. 
Rotter, J. (1967) 'A new scale for the measurement of interpersonal trust', Journal of Personality, Vol. 35, No. 4, pp.651-665.

Rufín, R., Bélanger, F., Molina, C.M., Carter, L. and Figueroa, J.C.S. (2014) 'A cross-cultural comparison of electronic government adoption in Spain and the USA', International Journal of Electronic Government Research, Vol. 10, No. 2, pp.43-59.

Schedler, K. and Summermatter, L. (2007) 'Customer orientation in electronic government: motives and effects', Government Information Quarterly, Vol. 24, pp.291-311.

Schwalbe, K. (2007) Information Technology Project Management, Thomson course Technology.

Shirazi, F., Gholami, R. and Añón Higón, D. (2009) 'The impact of information and communication technology (ICT), education and regulation on economic freedom in Islamic Middle Eastern countries', Information \& Management, Vol. 46, No. 8, pp.426-433.

Swanson, S. (2002) 'Faith in e-government tempered by security, privacy concerns', InformationWeek, Available online at www.informationweek.com/story/IWK20020226S0007, (accessed on January 10, 2014).

The Global E-Government Outlook (2002) McConnell International, Available online from zhangroup.aporc.org/BookEGovernmentStrategyPlanning/files.xml? (accessed on January 10, 2015).

Tolbert, C.J. and Mossberger, K. (2006) 'The effects of e-government on trust and confidence in government', Public Administration Review, Vol. 66, No. 3, pp.354-369.

Tolbert, C.J., Mossberger, K. and McNeal, R. (2008) 'Institutions, policy and e-government in the American states', Public Administration Review, Vol. 68, No. 3, pp.549-563.

Turban, E., King, D., Lee, J.K., Liang, T.P., and Turban, D.C. (2015) 'Innovative EC systems: from e-government to e-learning, collaborative commerce, and c2c commerce', Electronic Commerce, pp.209-254.

UNDP (2013) 'ICTs and e-governance in UNDP: 2013 status report', Available at: https://www.undpegov.org/sites/undpegov.org/files/e-gov-Mapping-2013-10-28_0.pdf (accessed May 02, 2015).

Von Bertalanffy, L. (1976) General System Theory: Foundations, Development, Applications, George Braziller, New York, NY.

Weerakkody, V., El-Haddadeh, R., Al-Sobhi, F., Shareef, M.A. and Dwivedi, Y.K. (2013a) 'Examining the influence of intermediaries in facilitating e-government adoption: an empirical investigation', International Journal of Information Management, Vol. 33, No. 5, pp.716-725.

Weerakkody, V., Irani, Z., Lee, H., Osman, I., and Hindi, N. (2013b) 'E-government implementation: a bird's eye view of issues relating to costs, opportunities, benefits and risks', Information Systems Frontiers, Vol. 17, No. 4, pp.889-915.

Wei, J., Liu, L.C. and Koong, K.S (2006) 'An onion ring framework for developing and assessing mobile commerce security', International Journal of Mobile Communications, Vol. 4, No. 2 , pp.128-142.

Welch, E.W., Hinnant, C.C. and Moon, M.J. (2005) 'Linking citizen satisfaction with e-government and trust in government', Journal of Public Administration Research and Theory, Vol. 15, No. 1, pp.37-58.

West, D.M. (2004) 'E-government and the transformation of service delivery and citizen attitudes', Public Administration Review, Vol. 64, No. 1, pp.15-27.

World Bank (2008) E-government, Definition of e-Government. Available online at http://go.worldbank.org/M1JHE0Z280, (accessed on January 10, 2015).

Yang, J., Harris, E.M. and Whitfield, M. (2009) 'E-government application in promoting local tourism: an empirical study', Electronic Government, An International Journal, Vol. 6, No. 1, pp.54-69. 